\title{
Hotel chains: survival strategies for a dynamic future
}

\section{Brendan Richard}

Brendan Richard is based at the University of Central Florida, Orlando, Florida, USA.
Received 28 June 2016 Revised 5 August 2016 Accepted 31 August 2016

(c) Brendan Richard. Published in the Journal of Tourism Futures.

This article is published under the Creative Commons Attribution (CC BY 4.0) licence. Anyone may reproduce, distribute, translate and create derivative works of this article (for both commercial and non-commercial purposes), subject to full attribution to the original publication and authors. The full terms of this licence may be seen at: http://creativecommons.org/ licences/by/4.0/legalcode

\begin{abstract}
Purpose - The purpose of this paper is to better understand the future of hotel chains by exploring the evolving expectations of guests, potential innovations, emerging opportunities, and likely future scenarios. Design/methodology/approach - A literature review consisting of current events, industry reports, and recent trends is utilized to summarize and categorize the challenges and opportunities facing hotel chains. Findings - The future of hotel chains will be driven by the convergence of an increasingly competitive landscape, along with a diverse evolving customer base seeking out unique and individualized experiences. In order to survive in the future hotel chains will have to: listen to and learn from guests incorporating big data insights, go beyond segments to provide personalized services, continuously develop the brand through signature experiences, utilize collaboration and open innovation to maintain an edge in technology and service, and through total revenue management generate ancillary revenues and maximize guest spend.
\end{abstract}

Originality/value - This paper provides a comprehensive set of recommendations to hotel chains highlighting opportunities related to: financing, revenue generation, personalization, and co-creation.

Keywords Futures, Hospitality, Hotel

Paper type Viewpoint

The capability is there for hotel companies to continue to develop and grow in their product. And the guest continues to be demanding, which they should, and wants to have things like technology and advanced opportunities [...] We in the hotel business are able to deliver that (Arne Sorenson, CEO, Marriott International).

The world is witnessing tremendous growth, not only in population size, but in its burgeoning middle classes and their discretionary income. Among the various sectors that drive the global economy, the tourism industry is one of the fastest growing, accounting for nearly one-third of the global services trade, one-tenth of global GDP, and one-tenth of all jobs. In 1950, international tourist arrivals numbered only 25 million, by 2013 that number had grown to over one billion, and with an expected annual growth rate of 3.3 percent, arrivals are expected to reach 1.8 billion by 2030 (United Nations World Trade Organization, 2014). A highly fragmented industry, the largest hotel chains employ over 100,000 employees in their over 6,000 hotels and they are growing (International Labour Organization (ILO), 2010). The five leading branded hotel companies account for over 41 percent of the global branded hotel market and have over 72 percent of the global development pipeline (Intercontinental Hotel Group, 2013). As they continue this period of growth hotel chains will also drive revenue growth through international expansion, innovative financial structuring, and total revenue management (RM).

Increasingly though, growth opportunities will be more complex and challenging for hotel chains. The one-size-fits-all approach will give way to a more unique personalized experience. Guests are becoming more diverse, both demographically and in their expectations (Yeoman et al., 2016). Globally, an exploding middle class in emerging nations will necessitate brand restructuring to accommodate a more diverse customer base. Millennials, already a significant percent of the global workforce are, more so than previous generations, social beings that crave instant satisfaction, exploration, and smart spending (Ernst \& Young (EY), 2014). To meet the challenges raised by changing expectations in customers, hotel chains will have to master the collection and 
analysis of big data to understand the impact of those changes. Moreover, to find new and innovative ways to respond to those changes, hotel chains will need to master the wisdom of the crowd, and open themselves up to innovation using knowledge available from external partners in order to create new differentiated personalized experiences.

In order to sustain and grow their competitive position in the future hotel chains will have to: listen to and learn from guests incorporating big data insights, go beyond segments to provide personalized services, continuously develop the brand through signature experiences, utilize collaboration technologies and open innovation to maintain an edge in their service experiences, and, through total RM, generate ancillary revenues and maximize guest spend. In this paper we explore the evolving expectations of guests, the drivers of change in the lodging industry, potential innovations, emerging opportunities, and likely future scenarios.

\section{Staying competitive}

Even during periods of rising revenues, hotel chains must be vigilant in protecting against profit erosion. Globally the pace of hotel openings is expected to pick up, potentially leading to decreased performance. With investors increasingly focused on purchasing better assets, and a more limited supply of assets projected to become available in core markets, competition is anticipated to heat up, with investments shifting to secondary markets (Jones Lang LaSalle (LaSalle), 2014).

Online travel agencies and internet consolidators will continue to play a strong role in the market (Oskam and Zandberg, 2016), charging substantial commissions. Further challenging hotel chains negotiating position is the recent consolidation within the industry. While industry analysts predict that the acquisitions would not have an impact on consumer prices, they do believe it will give hotel chains less leverage in negotiating hotel rates and commissions, potentially challenging growth in hotel revenues (Tuttle, 2015). Threats also exist from industry disruptors (Oskam and Boswijk, 2016; Richard and Cleveland, 2016). Since its founding in 2008, Airbnb has grown to over 800,000 listings in 600 cities across 190 countries, serving 17 million guests (Perez, 2014). One study found that in one market for every 10 percent increase in Airbnb listings, hotel revenue was reduced by 0.37 percent (Zervas et al., 2014). As the web enables growth in an increasingly collaborative economy, the challenge for hotel chains is how to innovate and adapt to accommodate this collaborative technology.

To successfully confront these challenges, hotels chains will have to be aggressive in their methods of financing their growth and maximizing their profitability: seeking out new funding structures, generating revenue through expansion into growth markets, maximizing revenue and profitability via total RM, and striving to maintain differentiated personalized products and services (Perez, 2014).

\section{Financing the future}

The existence of real estate investment trusts (REITs) and private equity (PE) funds has led to changes in the ownership structure within hotels. Hotel REITs carry with them advantages such as high liquidity, lower risk, and higher returns (Fresnel, 2009). Among Marriott's over 3,800 hotels, for example, a portfolio estimated at $\$ 150$ billion, almost all are owned by either REITs, PE or large investors. Nikhil Bhalla of FBR Capital Markets justifies the shift toward REITs by noting that "Real estate comes with a lot of debt, and that causes variables in the bottom line [...] When you do what Marriott does you do away with that risk, and your revenue comes straight from the top line" (Touryalai, 2013). Hotel chains utilizing REITs have accelerated property sales, in most cases leasing the sold property through long-term management contracts. Shareholders benefit from this arrangement through share buybacks and dividends resulting from the property sales (ILO, 2010). PE capital raises, invests and manages funds directly in companies, typically expecting higher rates of return from their investments than the stock market. PE funds are typically focused on short-term investments (three to five years), buying out a company, developing it, then bringing the company public or selling it (ILO, 2010).

In the past five years, post-recession in the USA, hotel investments have grown substantially with global hotel transactions projected to reach nearly $\$ 50$ billion. In 2012 alone, the largest net 
buyers were PE funds, utilizing almost $\$ 7$ billion in capital for hotel investments. REITs and PE buyers together comprised almost 70 percent of the total acquisition volume in the Americas (LaSalle, 2014). Driven by higher revenues and earnings over the past few years there are more lenders in the market today, with financing available for a more diverse set of projects. The perception exists that the bank market has become much more comfortable with hotels, especially branded hotels, offering higher loan-to-value ratios than could be obtained after the last recession (Hoisington, 2015; Mayock, 2015). Risks still exist though. Globally hotel openings are gaining pace, and an increasing supply pipeline is expected which could limit the performance of investments. In emerging markets, PE firms exiting investments may face challenges in identifying investors, pushing the firms to exit via an IPO or REIT (LaSalle, 2014).

\section{Targeting growth markets}

We have courtside seats at the global economy (Frits van Paasschen, CEO, Starwood Hotels and Resorts Worldwide).

With an expected annual growth rate of 3.6 percent the world GDP is expected to swell to $\$ 90$ trillion by 2020, a 40 percent increase from 2010. While mature economies currently represent two-thirds of the global GDP, by 2020 that proportion is expected to drop to 58 percent, as developing and emerging economies continue to contribute to a higher percent of world GDP growth (Harris et al., 2011). The growth in hotel investment will also shift to developing and emerging economies. Relative to mature economies, key countries in Latin America, the Middle East, and Asia will register disproportionate growth over the next decade, driven by the attractiveness of economic growth, technology transfer, and an investment in infrastructure (LaSalle, 2014).

In Latin America, "approximately 430,000 new rooms dispersed across more than 200 emerging markets in the region could be required throughout the next decade, representing a 65 percent increase over a 10-year period" (LaSalle, 2014, p. 12). Brazil represents the largest opportunity in this region, driven by home-grown demand and real GDP per capita increases $(\$ 11,000$ in 2010 to $\$ 15,000$ in 2020), although potential risks include: a restrictive financing environment, a bureaucratic business environment, and insufficient infrastructure. Columbia, Chile, and Peru also represent opportunities as dynamic growth opportunities, driven by interest from intra-regional investors based on economic growth projections, macroeconomic stability, and improving business environments (Harris et al., 2011; LaSalle, 2014).

In the Middle East, Dubai, Saudi Arabia, and Qatar stand out as opportunities for expansion where there exists a disparity between supply and demand. Dubai has over 82,000 hotel rooms, but that number will need to double by 2020 to accommodate the anticipated yearly demand of nearly 20 million visitors. Dubai has plans in place to invest over $\$ 8$ billion in new infrastructure, including hotels, to address this imbalance in preparation for the 2020 World Expo. Saudi Arabia, bolstered by business travel in conjunction with its oil industry, and religious tourism to its holy cities, has a current pipeline of approximately 30,000 hotel rooms (LaSalle, 2014). Qatar is also expected to see a boost in business travel which in addition to several projects related to hosting the World Cup in 2022 is expected to bring the total number of rooms from 19,000 to 34,000. Qatar has announced plans to invest a total of $\$ 20$ billion in tourism infrastructure to adequately prepare for the World Cup (Oxford Business Group, 2014).

In the Asia-Pacific region China is one of the fastest growing outbound travel markets, driven by increasing levels of discretionary income among the middle class. Between 2000 and 2010 outbound travel increased at a compound annual growth rate of 18.5 percent (10.5-57.4 million). Chinese tourists also have significant spending power, overtaking US tourists in 2012 as the world's largest spenders (EY, 2014). It is forecasted that over 40 percent of population growth in the middle class between 2010 and 2020 will come from China alone (Harris et al., 2011). Catering toward Chinese preferences will become even more important in the future as it is estimated that by 2020 there will be over 200 million Chinese outbound travelers (Deloitte Touche Tohmatsu Limited, 2011; EY, 2014).

Hotel chains that seek out expansion opportunities will ultimately have to decide how to expand, determining the optimal mix of equity (e.g. joint venture or full ownership) and non-equity

PAGE 58 J JOURNAL OF TOURISM FUTURES $\mid$ VOL. 3 NO. 12017 
(e.g. management contract or franchise) modes of entry. Unlike other service sectors, the hotel industry is capital-intensive, a potential obstacle to equity-based expansion models (Alon et al., 2012). As a result recent international expansion by hotel chains has been driven primarily by non-equity models of entry (Cunill and Forteza, 2010; Ivanova and Ivanov, 2014). Frequently hotel chains need to undergo a partner selection process in which they develop criteria for the evaluation and selection of a member hotel (Altinay, 2006). Hotel chains, in selecting a potential partner, focus on: location, characteristics, accessibility, and overall condition (Ivanova and Ivanov, 2015). Once a member hotel has entered into a partnership with a hotel chain it must begin the process of realigning its marketing policies with those of the hotel chain. Member hotels need to: adjust products to match market segmentation, align the product, standards, service and quality with the hotel chain's brand, revise the pricing structure, adapt to new suppliers, distribution channels, advertising, promotional materials, human resources policies and training (Ivanova, 2011).

\section{Total RM}

RM has evolved from a tactical, "value-adding" discipline to a strategic one, with an increasing impact on business. According to a recent survey of RM professionals (Kimes, 2011), 28 percent of respondents believe that RM "[will] become more strategic in nature." Moreover, professionals believe that RM "[will] encompass all revenue streams within the hotel," and will likely include budgeting and marketing into its scope (Milla and Shoemaker, 2008). The evolving roles and scope of RM will inevitably change the relationship between RM and other components of the hotel chain business. According to Milla and Shoemaker (2008), "some industry leaders are talking about a fully integrated RM function that oversees the marketing, sales, pricing and distribution functions of a hotel."

A significant portion of RM professionals believe that the future of RM will rely more on analytical models (Kimes, 2011). As stated by Davenport (2006), "analytics competitors are the leaders in their varied fields - consumer products, finance, retail, and travel and entertainment among them." In particular, one of the future trends predicted for RM is the inclusion of customer behavioral data into forecasts and optimizations (Bain, 2008; Kimes, 2011; Milla and Shoemaker, 2008). Social networks and big data technology are expected to become main drivers of this trend. Social networks data and text mining can help RM managers better understand the market conditions and the customer reactions to various RM strategies with respect to their competitors, and adjust marketing and pricing accordingly (Vinod, 2013).

For hotel chains, opportunities for the future include improvements in forecasting and optimization. Sophisticated demand forecasting and optimization models are being introduced to $\mathrm{RM}$ to better account for the impact of price transparency on customer choice (Vulcano et al., 2010). Though models considering customers' behaviors have been studied, successful applications of these theories are rare and more efforts are needed to transition theories to practice. Moreover, forecasting models for cancellations, dilutions, and no-shows are far from being mature. In addition, there are many challenges that exist for practitioners to achieve a higher level of forecasting accuracy: the dynamic nature of RM, the unpredictable change of schedules, the size of the problem, and the limitations of reservation systems (Chiang et al., 2007). On the optimization side, for network RM existing approaches still rely on decomposition approaches (Zhang, 2011).

These challenges cannot be met without proper RM systems, an advantage that hotel chains have over independent properties. In order to sell the right product to the right customer at the right price at the right time hotel chains must empower their RM teams with access to the right data, and provide them with advanced RM software to analyze it (Ivanov, 2014). Truly taking advantage of RM though, transforming the role from tactical to strategic, will require an organizational restructuring. Hotel chains should consider centralizing RM within its own department reporting directly to the general manager. Human resources should seek out revenue managers with strong analytical skillsets, knowledge of RM practices (both pricing and non-pricing) and the ability to communicate and partner with multiple stakeholders. While large hotels may retain an onsite revenue manager, small hotels might be regionally managed. To maximize efficiency hotel chains will need to counterbalance local knowledge with 
strategic expertise. Finally hotel chains should consider allowing RM the ability to oversee all revenue streams within the hotel, not merely just rooms. In order to act strategically hotel chains must revenue manage the entire property (Kimes, 2011).

\section{Personalizing the experience}

[We] need to focus more on creating a tighter or a closer relationship to [our] customers [...] Not only to mine customer data and [...] create revenue opportunities from that, but to provide customers with experiences that they want [...] to be even more user-friendly, more customizable, more personalized (Bob Iger, CEO, the Walt Disney Company; Bylund, 2015).

Hotel chains will be faced with the necessity of better understanding customers and using that understanding to provide customers with a more personalized experience. For hotel chains seeking to embrace the future, it is vital that they master: analyzing big data to understand their customers beyond simple segmentation, measuring and monitoring evolving customer expectations, and creating authentic experiences.

\section{Beyond segments}

It is imperative that hotel chains better understand their customers as unique individuals rather than statistical groupings. The manner in which hotel chains decide to market and sell to their customers will determine how successful they are in the future. Hotel chains can no longer afford to assign customers into clearly defined segments as they have in the past. The ubiquity of the internet and subsequent information transparency have made "knowing your customer" all the more important (Yeoman, 2011a, b). The current trend of guests seeking out personalized hotel experiences based on their unique preferences will continue and require hotel chains to continually innovate ways to respond (Amadeus, 2010). When RM professionals were asked what factors would drive change in the future, over 20 percent noted the necessity for more detailed market segmentation (Kimes, 2011).

In order to deliver a more personalized service customized to the needs of the traveler, hotels will have to rely more on the ability to collect, access, and analyze larger data sets, going past the more traditional methods of segmenting customers to understand their needs. Cindy Estis Green (CEO, Kalibri Labs) predicts that software will change to meet this demand. "You want to know about each individual consumer [...]. The technology has to enable this personal relationship [...]. Getting to that point is not about filling in more lines on a profile. It is about observing the consumer's behavior while staying in hotels, while searching for information, while talking about her experiences" (Amadeus, 2008, p. 12). Segmentation in the age of "big data" means incorporating activity-based data (e.g. website, call center, mobile, purchase history), social network profiles and social influence and sentiment data into analyses to enable more exact targeted marketing (Offsey, 2014).

Beyond the collection of data, and a more advanced level of analysis, guest motivations are likely to become more complex. In one survey 71 percent of professionals agreed that by 2020 "traveler motivations will become increasingly fragmented and diverse and harder to segment into clearly definable customer groupings" (Amadeus, 2010, p. 7). This shift to accommodating individual's expectations and preferences rather than market segments will impact hotels chains' ability to both acquire new guests and continue to serve their existing guests. By collecting more customer-specific data, and operating on a new level of "micro-segmentation," hotels will have the ability to better understand the preferences, motivations, and purchase decisions of their guests. In addition they will have a greater understanding of cost of servicing and the level of spend when targeting potential guests (Gurbuz, 2011).

In order to be successful increased data collection and more advanced analytics will have to be paired with revised marketing techniques. The substantial variation present within existing segments results in inefficient pricing and discount strategies. By "micro-segmenting" hotel chains have the opportunity to better understand their target market, while simultaneously avoiding marketing to their "anti-segments" (Offsey, 2014). It is important to identify those customers who hotel chains cannot service profitably, would consume too many resources, or who are less likely to remain loyal and/or be enticed into up-sell or cross-sell opportunities (Gladstein, 2013). 
For those customers who the hotel chain identifies as valuable, marketing can encourage loyalty by instilling a sense of "belongingness" to the hotel chain. This feeling of connectedness can be obtained through targeted offers that speak to the customer based on their "micro-segment." When companies provide targeted offers consumers are more likely to make a future purchase from the company (Infosys, 2013). Hotel chains can engage in micro-segment marketing to reach a potential customer at the best time through the best channel. Companies can engage via mobile devices with in-app messaging, push notifications, text messages, in addition to more traditional methods such as e-mails and website messages (McEwen, 2016). A center of marketing (Yeoman et al., 2016) mobile devices have become ubiquitous, and with a majority of consumers comfortable sharing data with retailers (Infosys, 2013), a valuable opportunity to offer targeted marketing to "micro-segmented" consumers.

\section{Evolving customer expectations}

A hotel brand can't stand apart just by having a comfortable, reliable, clean room [...]. We're not successful unless our guests are happy and having their expectations met and exceeded. And that expectation today, driven by technology, is personalization (Frits van Paasschen, CEO, Starwood Hotels and Resorts).

Modern travelers want to feel special, to have a personalized experience in which their expectations are met and their experiences are customized to meet their needs. According to Kimpton Hotels and Restaurants CEO Michael A. Depatie this "personalized, localized, authentic" experience is increasingly in opposition with the "one-size-fits-all chain approach." Moreover, this traveler is more knowledgeable than ever thanks to the advent of ubiquitous computing and Web 2.0 driven content sharing. This knowledge translates to a greater level of expectations of service and product offerings. As Chris Elam (Hyatt Hotels, Vice President central reservations) describes the trend: "In the past and even today, we force the customer to deal with us at regular points. Generally speaking that's check-in, check-out, wake-up calls, room service, things like that. The future will see us interact with them when they want us to [...] I think everything is going to evolve into multiple touch points based on customer desire" (Amadeus, 2008, p. 6).

More so than previous generations, Millennials seek out instant gratification, preferring fast service over friendly service and face-to-face contact. Millennials are social beings, actively engaging in social media, documenting and sharing their experiences online, and researching and submitting to crowdsourced review sites such as TripAdvisor. According to Kimpton Hotels and Restaurants CEO Michael A. Depatie Millennial customers are going to want to "to check in on the way from the airport [...] they may want to have an app to order room service [...] they're going to want to list a review on social media, maybe stop in the lobby and do a selfie" (Trejos, 2014, p. 1). Millennials are pickier about what they spend their money on, but have the ability to and are comfortable with last-minute purchase decisions. To win over Millennials hotel chains will have to provide the flexibility of automated service, embrace social media, and offer access to unique, individualized local experiences (EY, 2014).

Interacting with travelers on their terms includes not only managing service interactions with employees, but also developing a more comprehensive reservation system. The airline industry has already seen these enhancements, whereby a traveler cannot only book the flight, but also all of the accompanying features such as the seat and the meal at the time of purchase. Hotel chains have begun to pursue this path, with options such as which direction the room faces, and in some cases floor selection available via online booking. A completely seamless integrated experience is as of yet not available. One can imagine a future though in which every aspect of a traveler's hotel stay can be customized and reserved online.

\section{Co-creating the experience}

What we believe in first and foremost is listening to your guest, listening to potential customers (Kirk Kinsell, President of the Americas, InterContinental Hotels Group).

In order to provide and market unique experiences tailored to the individual preferences of a discerning customer, hotels chains will need to seek out new means of collecting and analyzing the massive amount of data that is now available to them. Collecting ideas on innovations need 
not be passive nor internal but can be gathered from a diverse and talented external crowd. Hotel chains can co-create innovative personalized experiences with not only their customers but the entire world. According to Chesbrough (2003) "companies are increasingly rethinking the fundamental ways in which they generate ideas and bring them to market - harnessing external ideas while leveraging their in-house R\&D outside their current operations" (p. 1). Open innovation has been and will continue to be an opportunity for some hotel chains to reinvigorate the innovation process, expanding it to include all stakeholders: employees, customers, brand followers, and the general public. The benefits of open innovation are numerous, including higher quality ideas, a greater quantity of ideas, and a reduction in cost and time to market (Richard et al., 2015; Sloane, 2011).

Several hotel chains, including Starwood, Hyatt, and Marriott, have begun to open up their innovation processes, partnering with the crowd to co-create solutions to their problems. By engaging the crowd through massive online focus groups and establishing innovation labs these hotel chains are centralizing and coordinating their open innovation efforts, reaping the benefits of mass-collaboration from existing and potential customers. At Marriott's Innovation Lab, for example, located within Marriott's headquarters in Bethesda, Maryland, employees are engaging in rapid-prototyping, with ideas generated in part from the crowd (Touryalai, 2013).

Crowdsourcing is expected to be an even more beneficial innovation technique for hotel chains seeking to adapt to new industry trends and customer preferences. Crowdsourcing allows the industry the ability to explore and discover innovations in a less costly, less time consuming and less resource intensive manner (Ford et al., 2015). Crowdsourcing can assist hotel chains in identifying new ways to expand into emerging markets while maintaining a local feel. Beyond globalization, Crowdsourcing has the potential to improve personalization as well. Crowds can be employed to best determine how employees should interact with customers to ensure an authentic, unique experiences.

\section{Conclusions}

Charting the path to success in the future will not be easy for hotel chains. The opportunities presented in this paper (inventive financing, emerging markets, total RM, thinking beyond segments, better understanding the customer, and co-creating experiences) cannot be attained without developing and executing a long-term strategy. Hotel chains will need to recommit themselves to pursuing better training and technology, attaining an enhanced understanding of their guests, creating authentic personalized experiences, maximizing all revenue streams, and determining where and how to expand.

The opportunity to move into new markets and operate on a truly global scale will come with several challenges. Hotel chains will have to ensure brand integrity, providing a consistent style of service across countries, while at the same time adapting services experiences and amenities to accommodate distinct cultures. Training and retaining staff will become critical, transferring knowledge into new markets, developing staff skills, and adapting to new technology will all become important success factors in entering these new and growing markets. Operating in these new markets requires an understanding of local preferences, customs, and cultural uniqueness (León-Darder et al., 2011).

The opportunity to better understand guests, their preferences and expectations, will also come with its own set of challenges. A more personalized service requires gaining access and acquiring the ability to analyze larger data sets, either in-house or via third party suppliers. Developing these competencies will require a commitment of organizational resources and leadership support. Co-creating solutions with guests will require a shift in organizational practices, retooling innovation labs to look outwards for answers and embracing social media. Finally, in order to benefit from insights obtained via larger data sets and co-creation activities organizations will have to develop a higher level of organizational flexibility.

For all of these technological wonders though: from intelligent hotels, to mobile apps, to virtual environments - a hotel chain must not lose sight of its brand and what differentiates it from its

PAGE $62 \mid$ JOURNAL OF TOURISM FUTURES $\mid$ VOL. 3 NO. 12017 
competitors. According to Best Western CEO David Kong, the real differentiator is the people, "We all read comment cards and letters that come to us [...] It's always about people [...] This industry is called the hospitality industry for a reason. If we, for the sake of technology and efficiency, give that up, then we'll be like the airlines. We'll be a commodity" (Trejos, 2014, p. 1).

\section{References}

Alon, I., Ni, L. and Wang, Y. (2012), "Examining the determinants of hotel chain expansion through international franchising", International Journal of Hospitality Management, Vol. 31 No. 2, pp. 379-86.

Altinay, L. (2006), "Selecting partners in an international franchise organisation", International Journal of Hospitality Management, Vol. 25 No. 1, pp. 108-28.

Amadeus IT Group (2008), "The future of the hotel industry: next month, next year, next decade - a blueprint for the future of the hotel industry", available at: www.amadeus.com/hotels/documents/hotels/Amadeus_The \%20future\%20of\%20the\%20hotel\%20industry.pdf (accessed January 6, 2016).

Amadeus IT Group (2010), "Hotels 2020: beyond segmentation - strategies for growth in an era of personalization and global change" available at: www.amadeus.com/web/amadeus/en_1A-corporate/Hotels/Resources-anddownloads/Research-reports/1319578304477-Page-AMAD_DocumentsPpal?assetid=1319609444141\& assettype=Categorizable_P\&industrySegment=1259068355773 (accessed January 6, 2016).

Bain, J. (2008), "Future of revenue management - from the plane to the shelf", Journal of Revenue and Pricing Management, Vol. 7 No. 3, pp. 302-6.

Bylund, A. (2015), "5 Things Walt Disney Co's management wants you to know", available at: www.fool.com/ investing/general/2015/02/15/5-things-walt-disney-cos-management-wants-you-to-k.aspx (accessed 20 January 2017).

Chesbrough, H.W. (2003), "The era of open innovation", MIT Sloan Management Review, Vol. 44 No. 3, pp. 35-41.

Chiang, W.C., Chen, J.C. and Xu, X. (2007), "An overview of research on revenue management: current issues and future", International Journal of Revenue Management, Vol. 1 No. 1, pp. 97-128.

Cunill, O.M. and Forteza, C.M. (2010), "The franchise contract in hotel chains: a study of hotel chain growth and market concentrations", Tourism Economics, Vol. 16 No. 3, pp. 493-515.

Davenport, T.H. (2006), "Competing on analytics", Harvard Business Review, Vol. 84 No. 1, p. 98.

Deloitte Touche Tohmatsu Limited (2011), “Hospitality 2015: tourism, hospitality, and leisure trends”, Deloitte Touche Tohmatsu Limited, New York, NY.

Ernst \& Young (EY) (2014), "Global hospitality insights: Top thoughts for 2014", available at: www.ey.com/Publication/vwLUAssets/EY_-_Global_hospitality_insights_2014/\$FILE/EY-Global-hospitalityinsights-2014.pdf (accessed January 6, 2016).

Ford, R., Richard, B. and Ciuchta, M. (2015), "Crowdsourcing: a new way of employing non-employees?", Business Horizons, Vol. 58 No. 4, pp. 377-88.

Fresnel, F. (2009), "Quick note on private equity groups", General Assembly of the EFFAT Hotel Restaurant Catering Tourism.

Gladstein, B. (2013), "Turn away a customer? Yes... if they are in your anti-segment", available at: www.ex plorics.com/turn-away-a-customer-yes-if-they-are-in-your-anti-segment (accessed January 6, 2016).

Gurbuz, E.G. (2011), "Revenue management operations in hotel chains in Finland”, bachelor's thesis, Saimaa University of Applied Sciences, Imatra (accessed January 6, 2016).

Harris, K., Schwedel, A. and Kim, A. (2011), "The great eight: trillion dollar growth trends 2020", available at: www.bain.com/publications/articles/eight-great-trillion-dollar-growth-trends-to-2020.aspx (accessed January 6, 2016).

Hoisington, A. (2015), "Lenders relish the hotel financing landscape", available at: www.hotelnewsnow.com/ Article/15567/Lenders-relish-the-hotel-financing-landscape (accessed January 6, 2016).

Infosys (2013), "Consumers worldwide will allow access to personal data for clear benefits, says Infosys study", available at: www.infosys.com/newsroom/press-releases/Pages/digital-consumer-study.aspx (accessed January 6, 2016). 
Intercontinental Hotel Group (2013), “Annual report 2013”, available at: www.ingplc.com/files/ reports/ar2013/ (accessed January 6, 2016).

International Labour Organization (ILO) (2010), "Developments and challenges in the hospitality and tourism sector", available at: www.ilo.org/wcmsp5/groups/public/@ed_norm/@relconf/documents/ meetingdocument/wcms_166938.pdf (accessed January 6, 2016).

Ivanov, S. (2014), Hotel Revenue Management: From Theory to Practice, Zangador, Varna.

Ivanova, M.G. (2011), "Marketing challenges faced by newly affiliated hotels", Proceedings of Second International Scientific Conference for PhD Candidates on Economics, Management and Tourism, Duni Resort, Bulgaria, May 6-8, pp. 427-32.

Ivanova, M. and Ivanov, S. (2014), "Hotel chains' entry mode in Bulgaria", Anatolia, Vol. 25 No. 1, pp. 131-5.

Ivanova, M. and Ivanov, S. (2015), "Affiliation to hotel chains: requirements towards hotels in Bulgaria", Journal of Hospitality Marketing \& Management, Vol. 24 No. 6, pp. 601-8.

Jones Lang LaSalle (LaSalle) (2014), "Hotel investment outlook global 2014", available at: www. joneslanglasalle.com/ResearchLevel1/JLL_HIO-Hotel-Investment-Outlook-2014_1.pdf (accessed January 6, 2016).

Kimes, S.E. (2011), "The future of hotel revenue management", Journal of Revenue and Pricing Management, Vol. 10 No. 1, pp. 62-72.

León-Darder, F., Villar-García, C. and Pla-Barber, J. (2011), "Entry mode choice in the internationalisation of the hotel industry: a holistic approach", The Service Industries Journal, Vol. 31 No. 1, pp. 107-22.

McEwen, L. (2016), "How to use micro-segmentation effectively in marketing automation”, available at: http:// monk.webengage.com/how-to-use-micro-segmentation-in-marketing-automation/ (accessed January 6, 2016).

Mayock, P. (2015), "Favorable financing bodes well for borrowers", available at: www.hotelnewsnow.com/ Article/16121/Favorable-financing-bodes-well-for-borrowers (accessed January 6, 2016).

Milla, S. and Shoemaker, S. (2008), "Three decades of revenue management: what's next?", Journal of Revenue and Pricing Management, Vol. 7 No. 1, pp. 110-14.

Offsey, S. (2014), "Micro-segmentation in the age of big data", available at: http://marketbuildr.com/blog/ segmentation-in-the-age-of-big-data/ (accessed January 6, 2016).

Oskam, J. and Boswijk, A. (2016), "Airbnb: the future of networked hospitality businesses", Journal of Tourism Futures, Vol. 2 No. 1, pp. 22-42.

Oskam, J. and Zandberg, T. (2016), "Who will sell your rooms? Hotel distribution scenarios", Journal of Vacation Marketing, Vol. 22 No. 3, pp. 265-78.

Oxford Business Group (2014), "Heavy lifting: Hotel investments are ramping up capacity ahead of 2022", available at: www.oxfordbusinessgroup.com/analysis/heavy-lifting-hotel-investments-are-ramping-capacityahead-2022 (accessed January 6, 2016).

Perez, S. (2014), "Airbnb CFO Andrew Swain has left the company", available at: http://techcrunch.com/20 14/09/18/airbnb-cfo-andrew-swain-has-left-the-company/ (accessed January 6, 2016).

Richard, B. and Cleveland, S. (2016), "The future of hotel chains: branded marketplaces driven by the sharing economy”, Journal of Vacation Marketing, Vol. 22 No. 3, pp. 239-48.

Richard, B., Ford, R. and Perry, W. (2015), "Crowdsourcing in the lodging industry: innovation on a budget", in Egger, R., Gula, I. and Walcher, D. (Eds), Open Tourism - Open Innovation, Crowdsourcing and Collaborative Consumption Challenging the Tourism Industry, Springer-Verlag, Berlin, pp. 79-94.

Sloane, P. (2011), "The brave new world of open innovation”, Strategic Direction, Vol. 27 No. 5, pp. 3-4.

Touryalai, H. (2013), "Marriott's upgrade: new CEO Arne Sorenson freshens up the brand for millennials", available at: www.forbes.com/sites/halahtouryalai/2013/06/26/marriotts-upgrade-new-ceo-arne-sorensonenlivens-the-hotel-giant-aims-for-1-million-rooms/2/ (accessed January 6, 2016).

Trejos, N. (2014), "Hotel CEOs talk free Wi-Fi, Twitter, room service", available at: www.usatoday.com/story/ travel/hotels/2014/02/27/usatoday-hotel-ceo-roundtable-marriott-kimpton-ing-choice-best-western/ 5495223/ (accessed January 6, 2016). 
Tuttle, B. (2015), "What expedia's acquisition of orbitz and travelocity means for travelers", Money, available at: http://time.com/money/3707551/expedia-orbitz-impact-travelers/ (accessed January 6, 2016).

United Nations World Trade Organization (2014), "Tourism highlights: 2014 edition", available at: www.e-unwto.org/doi/pdf/10.18111/9789284416226 (accessed January 6, 2016).

Vinod, B. (2013), "Leveraging BIG DATA for competitive advantage in travel", Journal of Revenue and Pricing Management, Vol. 12 No. 1, pp. 96-100.

Vulcano, G., van Ryzin, G. and Chaar, W. (2010), "Om practice-choice-based revenue management: an empirical study of estimation and optimization", Manufacturing \& Service Operations Management, Vol. 12 No. 3, pp. 371-92.

Yeoman, I. (2011a), "Ten years of revenue management", Journal of Revenue \& Pricing Management, Vol. 10 No. 1, pp. 1-7.

Yeoman, I. (2011b), "The changing behaviours of luxury consumption", Journal of Revenue \& Pricing Management, Vol. 10 No. 1, pp. 47-50.

Yeoman, I., Oskam, J. and Postma, A. (2016), "The future of hotels vacation marketing, service design and management”, Journal of Vacation Marketing, Vol. 22 No. 3, pp. 197-8.

Zervas, G., Proserpio, D. and Byers, J.W. (2014), "The rise of the sharing economy: estimating the impact of airbnb on the hotel industry", Research Paper Series, University School of Management, Boston, MA.

Zhang, D. (2011), "An improved dynamic programming decomposition approach for network revenue management", Manufacturing \& Service Operations Management, Vol. 13 No. 1, pp. 35-52.

\section{Further reading}

Van Paasschen, F. (2013), "Speech at Starwood Rendezvous New Orleans 2013", available at: http://skift. com/2013/08/30/starwood-ceo-defines-the-future-of-hotels-in-age-of-great-change/\#1 (accessed January 6, 2016).

\section{Corresponding author}

Brendan Richard can be contacted at: brendan.richard@ucf.edu

For instructions on how to order reprints of this article, please visit our website: 